Review

\title{
ARTIKEL REVIEW: PENGARUH PERLAKUAN PADA PATI SEBAGAI SUPERDISINTEGRAN TERHADAP WAKTU HANCUR FAST DISINTEGRATING TABLET
}

\section{REVIEW ARTICLE: THE EFFECT OF STARCH TREATMENT AS A SUPERDISINTEGRANT ON DISINTEGRATION TIME OF FAST DISINTEGRATING TABLET}

\author{
Gina Novita ${ }^{1}$, Dadih Supriadi ${ }^{2}$,Fenti Fatmawati ${ }^{*}$ \\ Fakultas Farmasi, Universitas Bhakti Kencana, Bandung, Indonesia, 40614 \\ *E-mail:fenti.fatmawati@bku.ac.id
}

Diterima: 16/03/2021

Direvisi: 22/03/2021

Disetujui: 24/04/2021

\begin{abstract}
Abstrak
Pati banyak digunakan dalam formulasi Fast Disintegratating Tablet (FDT) sebagai superdisintegran karena biodegradabilitas dan biokompatibilitasnya, namun beberapa kekurangannya seperti kompresibilitas, sifat alir dan daya serap terhadap air yang rendah dapat membatasi aplikasinya seperti mempengaruhi keseragaman bobot, kesulitan dalam mengempa tablet dan waktu hancur tablet lebih lama. Berbagai modifikasi pati baik secara fisika, kimia, enzimatis maupun kombinasi dilakukan untuk meningkatkan efektivitas penggunaan pati. Tujuan review jurnal ini untuk memberikan informasi mengenai pengaruh perlakuan pada pati dari berbagai sumber sebagai superdisitegran terhadap waktu hancur FDT. Pati hasil modifikasi memiliki permukaan granula pati lebih berpori berdasarkan hasil SEM dibandingkan pati alami. FDT menggunakan superdisintegran pati hasil modifikasi memiliki waktu hancur lebih cepat ( $<1$ menit) dibandingkan pati alami (2-3 menit). Komposisi pati yang digunakan dalam formulasi FDT dapat mempengaruhi waktu hancur tergantung dari sumber pati dan modifikasi pati yang dilakukan. Modifikasi pati secara kimia diantaranya mengkombinasikan pati xanthate dan CMC Na memiliki waktu hancur 12 detik, modifikasi pati beras ikatan silang karboksimetil dengan sodium silikat memiliki waktu hancur 16,83 detik dan modifikasi pati dengan konjugasi glycine memiliki waktu hancur 19 detik merupakan formula yang paling efektif digunakan sebagai superdisintegran dalam formulasi Fast Disintegrating Tablet.
\end{abstract}

Kata kunci: Fast Disintegrating Tablet; Modifikasi pati; Pati; Superdisintegran; Waktu Hancur 


\begin{abstract}
Starch was widely used in Fast Disintegratating Tablet (FDT) formulation as a superdisintegrant because of biodegradability and biocompatibility, but some disadvantages such as poor compressibility, flowability and water absorption, application was limited such as affecting weight uniformity, difficult compression and long disintegration time. Various physical, chemical, enzymatical or in combination modifications of starch for increased the effectiveness of starch. The aim of this journal review was to provide information on the effect of starch content from various sources as a superdisintegrant on the disintegration time of FDT. This journal review was conducted using the literature review method. The modified starch had a more porous starch granule surface based on the SEM results compared to natural starch. FDT used superdisintegrant modified starch had a faster disintegration time $(<1$ minute) than natural starch (2-3 minutes). The starch composition used in the FDT formulation affected the disintegration time depends on source and modification of starch used. Chemical modification of starch included combining starch xanthate and $\mathrm{CMC} \mathrm{Na}$ had a disintegration time 12 seconds, modification of cross-linked carboxymethyl rice starch with sodium silicate had a disintegration time 16.83 seconds and starch modification with glycine conjugation had a disintegration time 19 seconds were the most effective formula used. as a superdisintegrant in the Fast Disintegrating Tablet formulation.
\end{abstract}

Keywords: Fast Disintegrating Tablet; Modified Starch; Starch; Superdisintegrant; Disintegration Time

\title{
PENDAHULUAN
}

Bentuk sediaan farmasi oral seperti tablet dan kapsul merupakan sediaan yang paling banyak digunakan [1] karena pemakaiannya dapat dilakukan sendiri, ketepatan dosis, stabilitas yang baik dan praktis dibawa bepergian [2]. Kesulitan dalam menelan tablet secara utuh pada pasien terutama pediatri dan geriatri [3], maka dikembangkan penghantaran obat baru sediaan oral yaitu Fast Disintegrating Tablets (FDT). FDT merupakan tablet yang dapat langsung larut di rongga mulut saat kontak dengan saliva tanpa dikunyah dan tanpa bantuan air untuk melepaskan bahan aktif [1]. Waktu untuk disintegrasi umumnya <1 menit dan waktu hancur aktual yang dapat dialami pasien berkisar dari 5 detik sampai 30 detik [4]. Beberapa peneliti telah melakukan studi percobaan menggunakan berbagai macam bahan aktif sebagai model obat dalam pembuatan FDT diantaranya loratadin [5], domperidon [6][7], natrium diklofenak [8][9], ondansetron [10], salbutamol sulfat [11], famotidin [12], meloksikam [13], irbesartan [4] dan parasetamol [14]. FDT kemungkinan dapat meningkatkan bioavailabilitas obat yang mengalami metabolisme lintas pertama di hati dan obat yang bersifat hidrofobik. Zat aktif yang diformulasikan dalam bentuk sediaan FDT dapat diabsorpsi baik di daerah bukal, faring maupun esofagus selama larutan obat turun ke lambung [15].

Disintegrasi yang cepat pada FDT dipengaruhi oleh superdisintegran yang dapat menyebabkan efek gabungan dari pembengkakan (swelling) dan penyerapan air (water absorption). Permukaan tablet mudah terbasahi dalam air yang sedikit (saliva) karena superdisintegran memiliki afinitas tinggi terhadap air [16], sehingga disintegrasi dan disolusi tablet meningkat [17]. Terdapat tiga tipe superdisintegran yang dapat digunakan diantaranya Natural superdisintegrants, synthetic superdisintegrants dan co-processed superdisintegrants [18]. Natural superdisintegrant diantaranya getah biji dari Tamarindus indica (asam jawa) dan Cassia fistula (kayu raja/tengguli) [19], plantago ovata dan aloe vera [20], mango peel pectin 
[21]. Synthetic superdisintegrant diantaranya Ac-Di-Sol [5]; kombinasi Ac-Di-Sol dan kollidon CL [13]; sodium starch glycolate [11]. Co-processed superdisintegrant merupakan campuran lebih dari dua superdisintegran dengan menggunakan teknik yang berbeda diantaranya Ludiflash (campuran manitol (95\%), crospovidone (5\%) dan polivinil asetat (5\%) [22] dan F-melt (sakarida, zat penghancur dan eksipien anorganik) [23].

Berbagai sumber seperti beras, gandum, ubi jalar, talas, biji mangga, singkong, nangka mengandung pati masing-masing sebesar 76-90\%, 65-67\%, 70-73\%, 59,2-80,76\%, 70,76\%, $35,93 \%, 40-50 \%$ [24-26]. Kandungan pati yang berbeda ini dapat dipengaruhi oleh umur panen, varietas dan lingkungan (cahaya, keadaan tanah dan iklim) [27]. Pati banyak dimanfaatkan di bidang farmasi karena biodegradabilitas dan biokompatibilitas terutama digunakan sebagai pengisi, penghancur dan pengikat dalam tablet [6]. Penggunaan pati sebagai disintegran maupun pengikat tergantung konsentrasi yang digunakan. Umumnya, pati dapat digunakan sebagai superdisintegrant pada FDT pada konsentrasi 2-10\% [6]. Namun pati memiliki kekurangan sehingga dapat membatasi aplikasinya seperti kompresibilitas dan sifat alir rendah yang dapat mempengaruhi keseragaman bobot tablet dan kesulitan dalam mengempa tablet. Beberapa peneliti telah melakukan berbagai modifikasi pati baik secara fisik, kimia, enzimatis maupun kombinasi untuk meningkatkan efektivitas penggunaan pati [28].

Berdasarkan uraian diatas maka tujuan review jurnal ini adalah untuk memberikan informasi mengenai pengaruh perlakuan pada pati dari berbagai sumber sebagai superdisitegran terhadap waktu hancur FDT. Modifikasi pada pati dapat mengubah morfologi dan mempengaruhi ikatan hidrogen dengan terkontrol sehingga dapat mengubah sifat pati termasuk viskositas, struktur dan stabilitas umur simpan dalam produk akhir [29]. Perubahan morfologi ini dapat dilihat secara visual dengan menggunakan Scanning Electron Microscope (SEM) dengan berbagai skala pembesaran.

\section{Karakterisasi dengan Scanning Electron Microscope (SEM) Pati Alami}

Scanning Electron Microscope (SEM) digunakan untuk mengamati morfologi bentuk dan ukuran granula pati baik pati alami maupun pati termodifikasi. SEM merupakan jenis mikroskop elektron yang menggunakan berkas elektron dalam menggambarkan bentuk permukaan dari suatu sampel. Berdasarkan permukaan dan adanya pori-pori pada pati dari hasil visualisasi dengan menggunakan SEM dapat dilihat pada Gambar 1 bahwa pati kentang dan kacang memiliki permukaan halus tanpa pori-pori. Pati jagung memiliki permukaan halus dengan poripori bulat. Pati gandum memiliki permukaan paling halus dari semua pati, tanpa pori-pori. Pati beras memiliki tekstur permukaan yang halus dengan beberapa pori kecil dan bulat. Sebagian besar pada pati jagung dan beras berpori, sedangkan pati dari kentang, kacang dan gandum tidak berpori atau jumlah pori-pori yang sangat terbatas. Granula pati dalam biji E scandens (k) ditutupi dengan beberapa massa lendir/resin, granula pati berbentuk bulat padat [30]. 


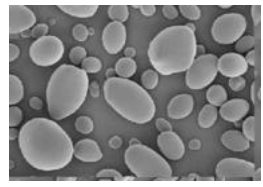

(a)

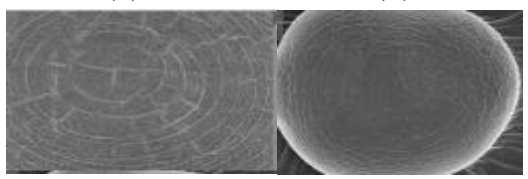

(f)

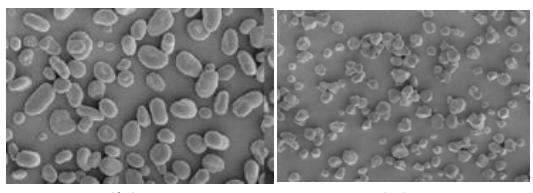

(c)

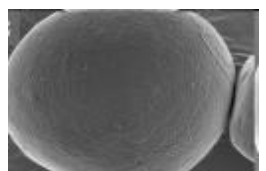

(h)

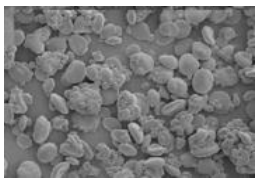

(d)

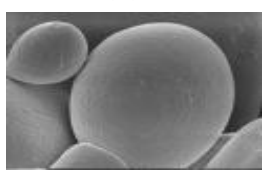

(i)

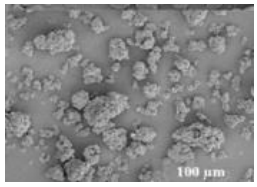

(e)

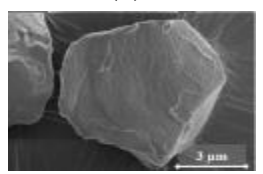

(j)

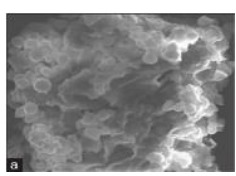

(k)

Gambar 1. SEM photomicrograph (a dan f) Pati kentang (b dan g) Pati kacang (c dan h) Pati jagung (d dan i) Pati gandum (e dan j) Pati beras (k) Pati biji Entada scandens. Perbesaran 1000x (a-e). Perbesaran 25000x (f-j) [30] [31]

\section{Karakterisasi dengan Scanning Electron Microscope (SEM) Pati Modifikasi}

Berdasarkan Gambar 2. pati jagung mengalami perubahan dari struktur pati yang halus, permukaan datar dengan tepi terlipat menjadi bentuk tiga dimensi setelah konjugasi dengan Neusilin UFL2. Konjugasi pati jagung-Neusilin UFL2 menunjukkan adanya rongga yang bertanggung jawab dalam peningkatan daya serap air dan kapasitas pembengkakan dibandingkan dengan pati jagung alami. Konjugat dengan metode microwave (d) menujukkan struktur berpori dibandingkan dengan konjugat dengan metode kimiawi (c) [6]. Ikatan silang karboksimetil pati nangka pada Gambar 3 (a) menunjukkan sedikit perubahan di permukaan granul dibandingkan pati nangka alami (b) dengan adanya fragmen kecil karena adanya reaksi ikatan silang. Adanya modifikasi ikatan silang karboksimetil secara signifikan mengubah struktur butiran pati pada lingkungan basa [32].

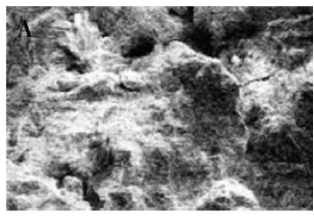

(a)

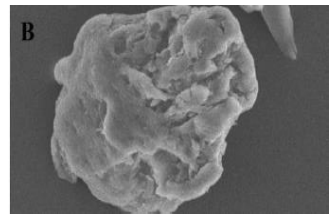

(b)

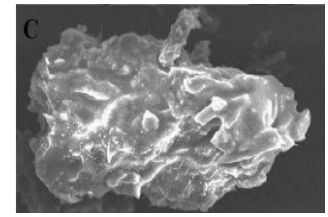

(c)

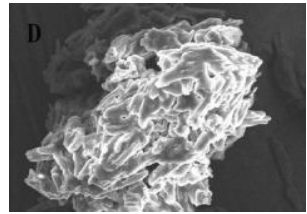

(d)

Gambar 2. SEM photomicrograph (a) Pati jagung (b) Konjugasi pati jagung-Neusilin UFL2 dengan metode fisika (c) Metode kimia (d) Metode microwave [6]

Berdasarkan Gambar 4. pati beras alami (a) memiliki bentuk polihedral yang tidak beraturan, sedangkan pati dengan koproses dan siliko dioksida (c) memiliki bentuk aglomerat bulat dengan permukaan halus, partikel kecil silikon dioksida teradsorpsi dan dapat terlihat pada permukaan partikel [33]. Ikatan silang karboksimetil pati beras (b) memiliki bentuk yang tidak beraturan, ukuran butiran kecil $(5 \mathrm{~nm})$ dan partikel sama dengan pati beras alami tetapi permukaan lebih bulat [34]. 


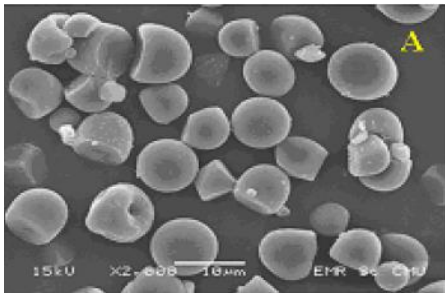

(a)

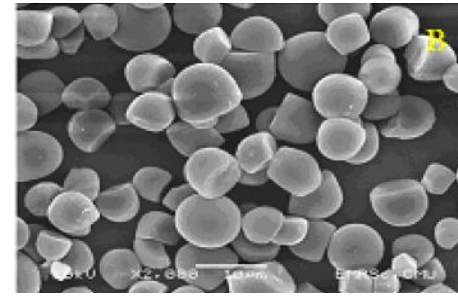

(b)

Gambar 3. SEM photomicrograph (a) Ikatan silang karboksimetil pati nangka (b) Pati nangka Perbesaran 2000x [35]

Permukaan yang menyusut pada pati ikatan silang karboksimetil ini terjadi karena efek dari alkohol dan air dalam persiapan proses koproses. Penambahan alkohol menyebabkan butiran pati menyusut dan membatasi efek pembengkakan air [36]. Berdasarkan dari hasil gambar SEM berbagai sumber pati diatas menunjukkan bahwa terdapat pengaruh secara signifikan terhadap permukaan granula pati alami dengan pati termodifikasinya, dimana pati hasil modifikasi secara umum lebih berpori dibandingkan pati alaminya.

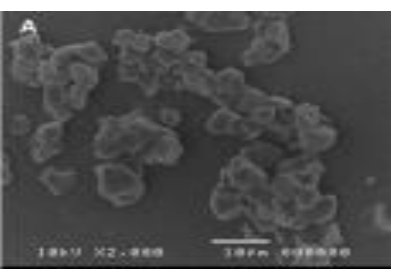

(a)

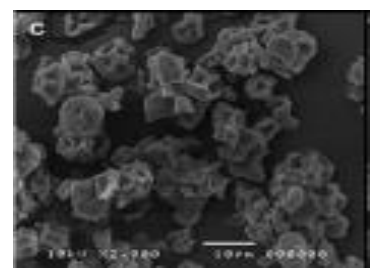

(b)

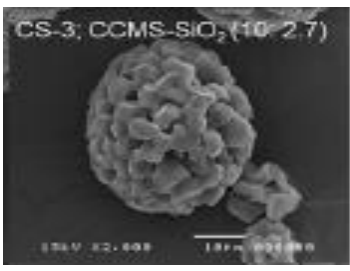

(c)

Gambar 4. SEM photomicrograph (a) Pati beras (b) Ikatan silang karboksimetil pati beras dengan sodium silikat (c) Koproses dari pati beras dan silikon dioksid [9][10]

Perubahan pati setelah dimodifikasi dapat terlihat dari interaksi senyawa kimia pati dengan agen modifikasi yang digunakan dengan mengidentifikasi gugus fungsi yang terbentuk menggunakan Fourier Transform Infra Red (FTIR). Selain itu analisa menggunakan FTIR ini dapat digunakan untuk melihat ada atau tidaknya interaksi antara pati alami atau termodifikasi dengan bahan aktif yang digunakan. Karena kriteria bahan tambahan yang digunakan dalam pembuatan tablet diantaranya tidak toksik, inert secara fisiologis, stabil secara fisik dan kimia, bebas mikroba dan kompatibel [37].

\section{Analisis Fourier Transform Infra Red (FTIR)}

FTIR dapat mengukur serapan radiasi inframerah berdasarkan pada interaksi senyawa kimia dengan radiasi elektromagnetik dan menghasilkan suatu getaran (vibrasi) pada berbagai panjang gelombang [38]. Pada Gambar 5. menunjukkan adanya puncak baru pada $1670 \mathrm{~cm}^{-1}$ dan 1750 $\mathrm{cm}^{-1}$ menandakan adanya regangan amida dan kelompok ester yang menandakan adanya leusin pada pati (b). Peningkatan intensitas gugus ester menguatkan keberhasilan esterifikasi leusin terlindungi dipati. Adanya gugus amina dan ester pada protected leucine grafted starch (d) [7]. Konjugat pati glisin pada Gambar 6. menunjukkan luas puncak antara 3200-3600 cm-1 dan 1600 - 
$1800 \mathrm{~cm}^{-1}$ sesuai dengan gugus asam karboksilat dalam struktur pati dan pembentukan pati konjugat glisin [39].

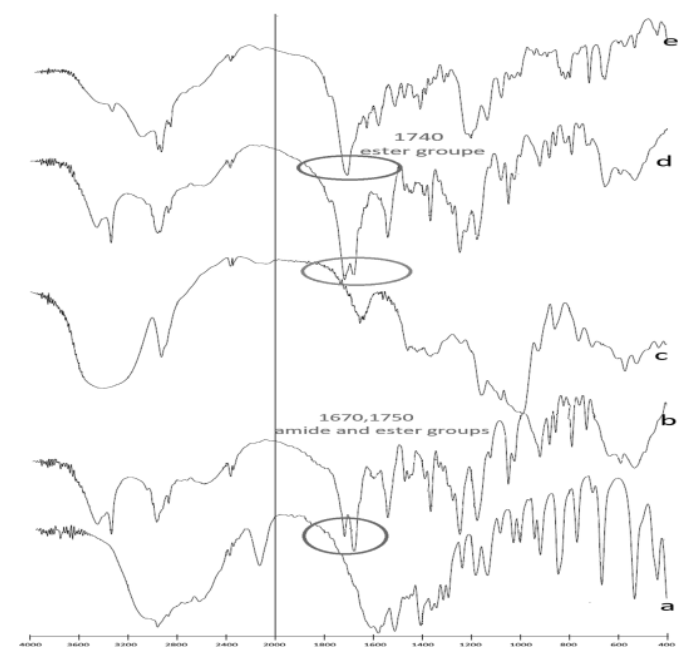

Gambar 5. Spektrum FTIR (a) leucine (b) protected leucine (c) pati (d) protected leucine grafted starch (e) leucine grafted starch [7]

Berdasarkan Gambar 7. konjugat pati jagung-Neusilin UFL2 yang dibuat dengan metode fisik, microwave mixture, dan kimiawi menunjukan adanya puncak tajam di dekat $3480 \mathrm{~cm}^{-1}$. Penajaman puncak menunjukkan pembentukan ikatan penghubung $\mathrm{Si}-\mathrm{O}-\mathrm{C}$ antara pati jagung dan Neusilin UFL2. Pengurangan intensitas puncak pada $1241 \mathrm{~cm}^{-1}, 1159 \mathrm{~cm}^{-1}, 1080 \mathrm{~cm}^{-1}$ menegaskan jembatan antar molekul antara pati jagung dan Neusilin UFL2, sehingga dengan penambahan neusilin ini dapat mengubah sifat pati jagung membentu suatu eksipien baru dengan sifat fungsional yang berbeda [6].

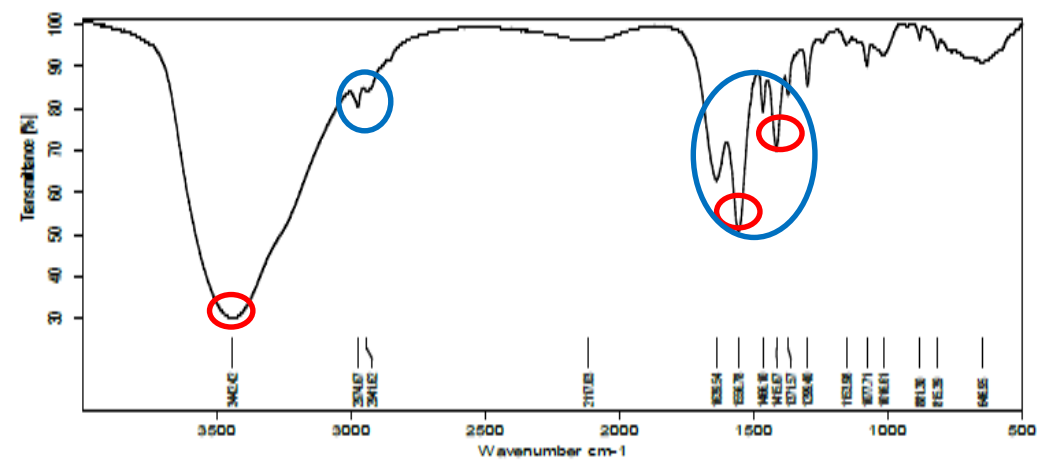

Gambar 6. Spektrum FTIR Konjugat pati glycine [39]

Spektrum FTIR dari polysuccinimide yang ditunjukkan pada Gambar 8. menunjukkan pita tajam pada $1660 \mathrm{~cm}^{-1}$ dan peregangan pada $3500-3700 \mathrm{~cm}^{-1}$ menunjukkan cincin imida dan peregangan $\mathrm{N}-\mathrm{H}$. Derivatisasi pati oleh polysuccinimide telah dikonfirmasi dengan adanya puncak pada $1750 \mathrm{~cm}^{-1}$, dikaitkan dengan pembentukan ikatan sterik dan gugus imida dan amina 
dari polysuccinimide. Adanya ikatan ester yang baru terbentuk antara gugus hidroksil pati dan gugus karbonil dari rantai polysuccinimide pada $1750 \mathrm{~cm}^{-1}[10]$.

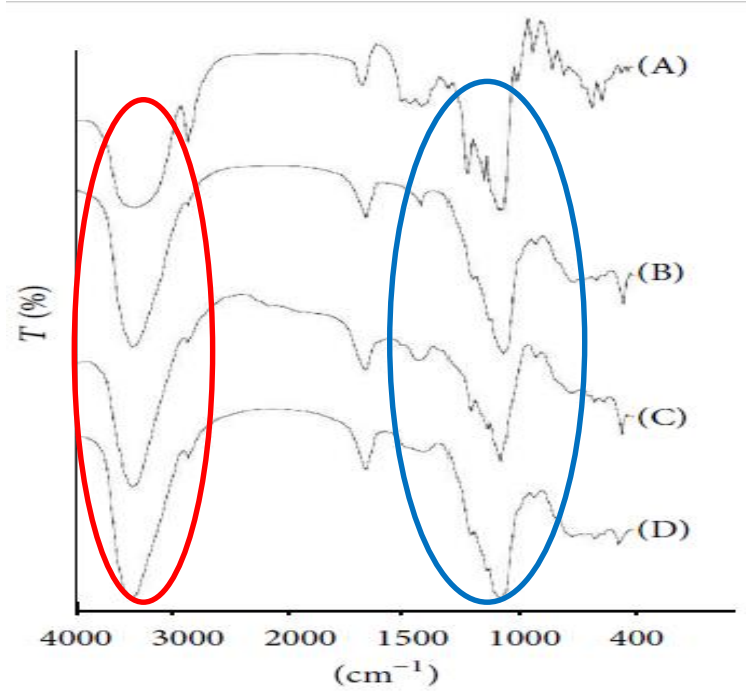

Gambar 7. Spektrum FTIR (a) Pati jagung (b) Konjugasi pati jagung-Neusilin UFL2 dengan metode fisika (c) Metode kimia (d) Metode microwave [6]

Spektrum FTIR Gambar 9. ibuprofen (b) terdapat puncak pada panjang gelombang $1718,78 \mathrm{~cm}^{-1}(\mathrm{COOH})$, dan ibuprofen-pati xanthate (a) pada $1716,17 \mathrm{~cm}^{-1}(\mathrm{COOH})$ menunjukkan tidak adanya interaksi antara pati xanthate dan bahan aktif ibuprofen. Oleh karena itu, pati xanthate dapat digunakan sebagai superdisintegran dalam FDT ibuprofen. Adanya puncak serapan pada $1634,10 \mathrm{~cm}^{-1}$ menunjukan puncak ester, maka dari studi FTIR disimpulkan bahwa pati xanthate (ester) terbentuk saat pati dibiarkan bereaksi dengan asam format [40].

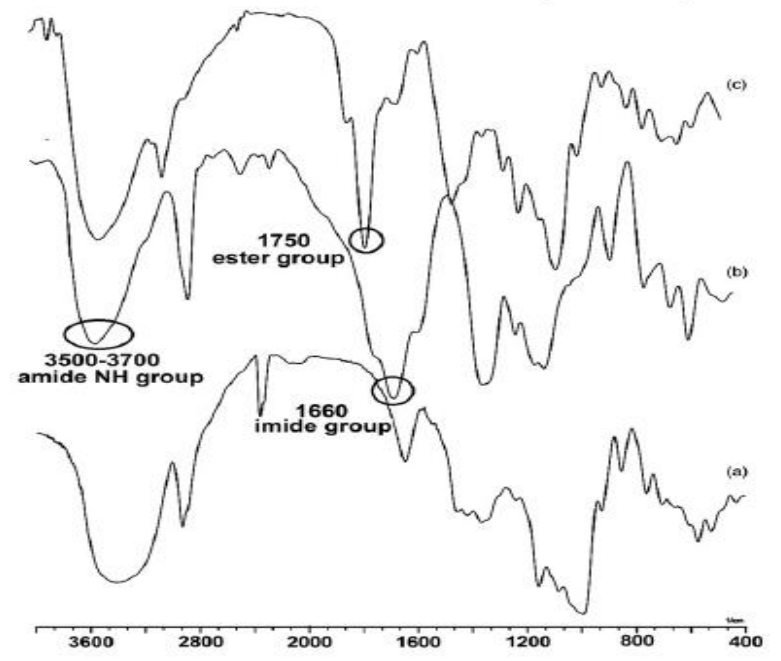

Gambar 8. Spektrum FTIR (a) Pati (b) Polysuccinimide (c) Metode kimia (d) Pati derivatisasi dengan polysuccinimide [10] 
Spektrum FTIR standar parasetamol menampilkan puncak luas getaran yang khas pada sekitar 3336,68 $\mathrm{cm}^{-1}(\mathrm{O}-\mathrm{H})$ dan $3151,34 \mathrm{~cm}^{-1}\left(\mathrm{CH}_{3}\right)$. Puncak getaran gugus karbonil $(\mathrm{C}=\mathrm{O})$ ditunjukkan peregangan pada $1673,49 \mathrm{~cm}^{-1}$. Cincin aromatik pada $691,19 \mathrm{~cm}^{-1}$ yang ditunjukkan pada Gambar 11. Adanya puncak yang sama pada standar PCT dan sampel campuran PCT dan AMS. Tidak adanya perbedaan spektrum pada kedua sampel tersebut dapat disimpulkan bahwa parasetamol kompatibel dengan AMS [41].

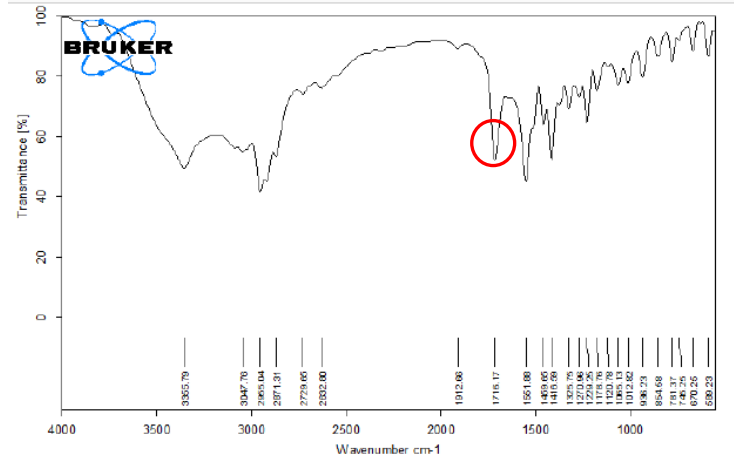

(a)

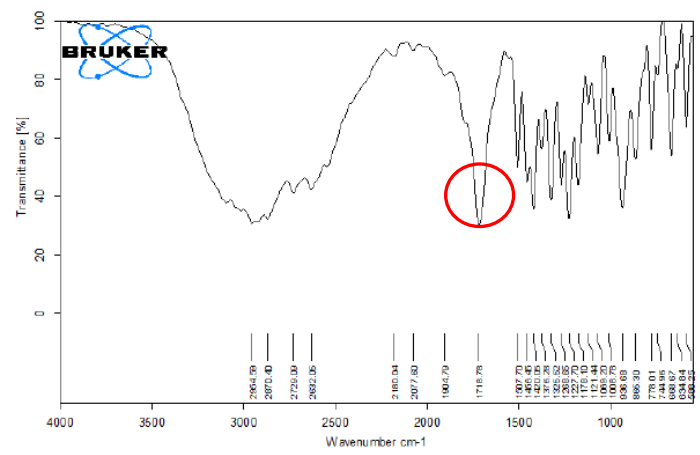

(b)

Gambar 9. Spektrum FTIR (a) Ibuprofen-pati xanthate (b) Ibuprofen [40] \

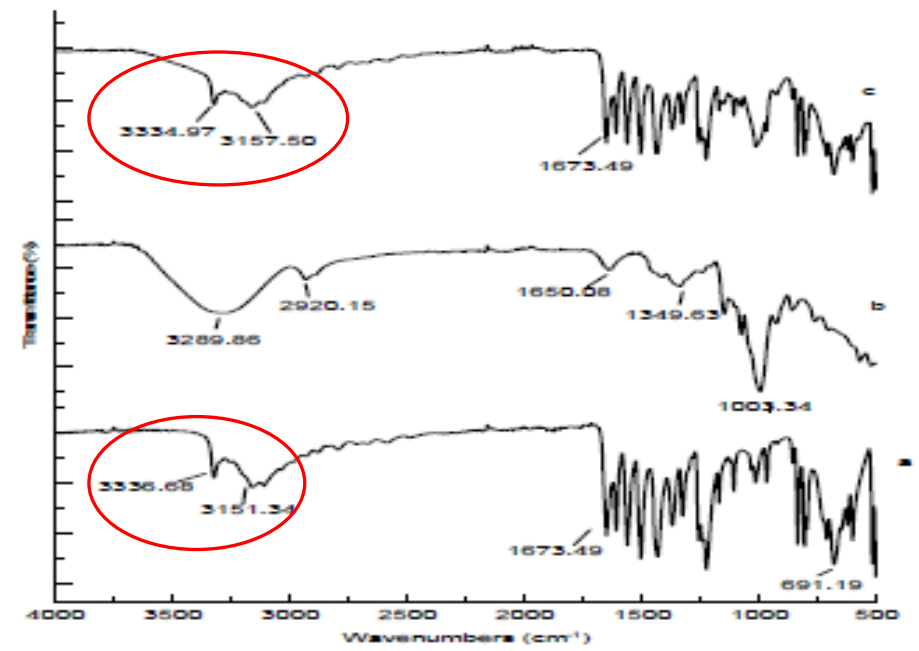

Gambar 10. Spektrum FTIR (a) Parasetamol (b) Pati Borassus aethiopum (Aracaceae) (AMS) (c) Parasetamol-AMS [41]

Pada spektrum FTIR Gambar 10. ikatan silang karboksimetil pati beras (b) terdapat gugus karbonil $(\mathrm{C}=\mathrm{O})$ dari gugus karboksilat $\left(\mathrm{COO}^{-}\right)$diamati pada panjang gelombang $1600 \mathrm{~cm}^{-1}$ yang menunjukkan substitusi gugus hidroksil dengan gugus karboksimetil. Peregangan $\mathrm{O}-\mathrm{H}$ pada $1648 \mathrm{~cm}^{-1}$, OH $3600-3000 \mathrm{~cm}^{-1}$ dan C-H membentang pada $2900 \mathrm{~cm}^{-1}$ terdeteksi pada pati beras 
(a) dan koproses dari pati beras dan silikon dioksid (10:0,5) (d). Gugus fungsi. Spektrum FT-IR pada eksipien koproses (d) tidak menunjukkan adanya puncak tambahan, atau pergeseran posisi puncak yang menunjukkan bahwa tidak ada interaksi kimiawi yang terjadi selama dilakukan proses secara bersamaan [33].

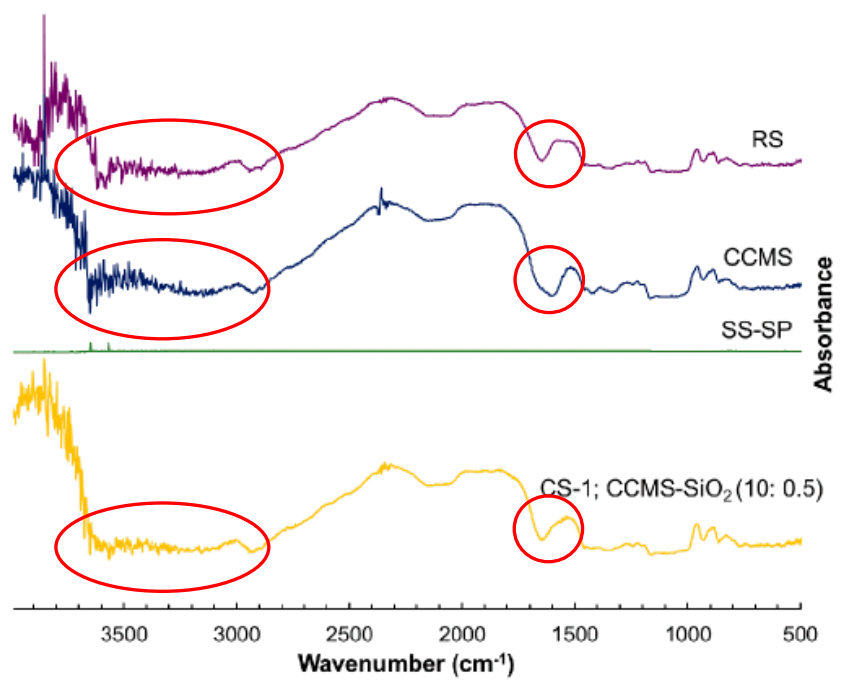

Gambar 11. Spektrum FTIR (a) Pati beras (b) Ikatan silang karboksimetil pati beras (c) Spray dried silikon dioksida (d) Koproses dari pati beras dan silikon dioksid (10:0,5) [33]

\section{Evaluasi Fast Disintegrating Tablet (FDT) dari berbagai sumber pati sebagai superdisintegran}

Superdisintegran alami jenis pati sebagai penghancur bekerja dengan mekanisme mengembang (swelling) ketika kontak dengan air yang menyebabkan melemahnya kohesi antar patikel dalam tablet sehingga tablet hancur [42]. Pati menjadi penghancur tablet tertua dan sudah banyak digunakan, namun karena sifat hidrofobiknya penyerapan terhadap air menjadi rendah sehingga konsentrasi pati yang digunakan harus lebih banyak agar dapat menghancurkan tablet secara cepat [43]. Beberapa peneliti telah melakukan berbagai modifikasi pati baik secara fisika, kimia, enzimatis maupun kombinasi untuk meningkatkan efisiensi penggunaan pati sebagai penghancur dengan konsentrasi yang lebih rendah [28].

Waktu hancur tablet merupakan parameter terpenting dalam pengembangan FDT yang harus cepat hancur didalam mulut dalam waktu <1 menit [4] atau kurang dari 3 menit [1]. Namun, pengujian waktu hancur berdasarkan kompendial belum efektif karena tidak mencerminkan disintegrasi FDT didalam mulut, sehingga selain waktu hancur diamati juga dengan pengujian wetting time dan water absorption ratio sebagai metode alternatif [44]. Uji waktu pembasahan (wetting time) untuk mengetahui waktu yang dibutuhkan FDT dalam menyerap air, sedangkan water absorption ratio menunjukkan kemampuan FDT dalam menyerap dan menampung air yang dinyatakan dalam persen massa air terhadap massa tablet basah [1][45]. 
Tabel 1. Evaluasi FDT menggunakan pati alami sebagai superdisintegran

\begin{tabular}{|c|c|c|c|c|c|c|c|c|}
\hline $\begin{array}{c}\text { Pati sebagai } \\
\begin{array}{c}\text { Superdisitegr } \\
\text { an }\end{array}\end{array}$ & $\begin{array}{c}\text { Kadar } \\
(\%)\end{array}$ & $\begin{array}{c}\text { WH } \\
(\text { detik })\end{array}$ & $\begin{array}{c}\text { WT } \\
(\text { detik })\end{array}$ & $\begin{array}{c}\text { WAR } \\
(\%)\end{array}$ & $\begin{array}{c}\text { Kekerasan } \\
\left(\mathrm{kg} / \mathrm{cm}^{2}\right)\end{array}$ & $\begin{array}{c}\text { Kerapuhan } \\
(\%)\end{array}$ & Disolusi & Sumber \\
\hline $\begin{array}{c}\text { Pati biji } \\
\text { Entada } \\
\text { scandens }\end{array}$ & 15 & - & 60 & - & $3,0-3,5$ & $0,2-0,4$ & $\begin{array}{c}98,65 \% \\
\text { menit } \\
\text { ke-60 }\end{array}$ & {$[30]$} \\
\hline Pati Jagung & 10 & 71 & 66 & 40 & $3,09-3,15$ & $0,89-0,91$ & $\begin{array}{c}30-45 \% \\
\text { menit } \\
\text { ke-60 }\end{array}$ & {$[6]$} \\
\hline Pati Kentang & 4 & 180 & - & - & $6,6-7,1$ & $\leq 0.5$ & $58 \%$ & {$[7]$} \\
\hline Pati Nangka & 2 & 284 & - & - & - & - & - & {$[35]$} \\
\hline Pati beras & - & 65,7 & - & - & - & - & - & {$[33]$} \\
\hline
\end{tabular}

Keterangan : WH (Waktu Hancur); WT (Wetting Time); WAR (Water Absorption Ratio)

FDT dengan menggunakan pati alami diantaranya pati biji Entada scandens, jagung, kentang dan nangka memiliki waktu hancur kurang dari 3 menit kecuali pati nangka dapat dilihat pada Tabel 1. Pati nangka tanpa modifikasi dengan konsentrasi $2 \%$ memiliki kemampuan sebagai superdisintegran meskipun tidak terlalu efektif yang ditunjukkan dengan waktu hancur lebih dari 3 menit (284 detik). Hal ini kemungkinan disebabkan dengan konsentrasi pati nangka yang digunakannya rendah. Pada pati kentang memiliki kekerasan $6,6-7,1 \mathrm{~kg} / \mathrm{cm}^{2}$, sedangkan kekerasan FDT yang baik adalah $3-5 \mathrm{~kg} / \mathrm{cm}^{2}$ sehingga hal ini kemungkinan menyebabkan waktu hancur tablet selama 180 detik. Kekerasan FDT umumnya lebih rendah dibandingkan tablet konvensional, karena dengan kekerasan yang tinggi dapat menunda disintegrasi tablet [46].

Tabel 2. Evaluasi FDT menggunakan pati hasil modifikasi secara fisika sebagai superdisintegran

\begin{tabular}{|c|c|c|c|c|c|c|c|c|}
\hline $\begin{array}{c}\text { Pati sebagai } \\
\text { Superdisitegran }\end{array}$ & $\begin{array}{c}\text { Kadar } \\
(\%)\end{array}$ & $\begin{array}{c}\text { WH } \\
(\mathrm{detik})\end{array}$ & $\begin{array}{c}\text { WT } \\
(\mathrm{detik})\end{array}$ & $\begin{array}{c}\text { WAR } \\
(\%)\end{array}$ & $\begin{array}{c}\text { Kekerasan } \\
\left(\mathrm{kg} / \mathrm{cm}^{2}\right)\end{array}$ & $\begin{array}{c}\text { Kerapuhan } \\
(\%)\end{array}$ & Disolusi & Sumber \\
\hline $\begin{array}{c}\text { Konjugasi pati } \\
\text { jagung- } \\
\begin{array}{c}\text { Neusilin UFL2 } \\
\text { physical } \\
\text { mixture })\end{array}\end{array}$ & 10 & 40 & 31 & 103 & $3,5-3,75$ & $0,71-0,76$ & $\begin{array}{c}70-85 \% \\
\text { menit ke- } \\
60\end{array}$ & {$[6]$} \\
\hline $\begin{array}{c}\text { Koproses dari } \\
\text { pati beras, } \\
\begin{array}{c}\text { CCMS dan } \\
\text { silikon dioksid }\end{array}\end{array}$ & $\begin{array}{c}10: 2, \\
7\end{array}$ & 28 & - & - & - & - & - & {$[33]$} \\
\hline
\end{tabular}

Keterangan : WH (Waktu Hancur); WT (Wetting Time); WAR (Water Absorption Ratio) 
Modifikasi pati secara fisika dilakukan dengan memberikan perlakuan panas, tekanan atau mekanik [28][47]. Konjugasi pati jagung-Neusilin UFL2 dengan pencampuran secara fisika dengan tumbling mixer menghasilkan sifat alir yang lebih baik yang dapat dilihat dari nilai sudut istirahat $\left(36,69^{\circ}\right)$, carr's index $(22,5 \%)$; hausner ratio $(1,29)$ jika dibandingkan dengan pati jagung alami sudut istirahat $\left(43,25^{\circ}\right)$, carr's index $(34,28 \%)$; hausner ratio $(1,52)$. Selain itu, pati hasil modifikasi ini memiliki nilai swelling index sebesar $40 \%$ yang jauh lebih baik dibandingkan pati jagung alami sebesar $18 \%$. Meningkatnya nilai swelling index menyebabkan waktu hancur dan wetting time FDT dengan pati hasil modifikasi lebih cepat (40 dan 31 detik) jika dibandingkan dengan pati jagung alami (71 dan 66 detik), sedangkan rasio penyerapan air berbanding terbalik dengan wetting time dan waktu hancur dapat dilihat pada Tabel 2 . Hal ini dapat disebabkan karena hancurnya tablet dapat dipengaruhi oleh porositas, konjugasi pati jagung-Neusilin UFL2 menunjukkan adanya rongga berdasarkan hasil SEM sesuai dengan nilai porositas yang didapat sebesar $37,5 \%$ dibandingkan pati jagung alami sebesar $18,4 \%$. Porositas yang tinggi dapat memfasilitasi penetrasi media air (saliva) kedalam tablet lebih cepat menyebabkan pembengkakan dan penyerapan pada konjugasi pati jagung-neusilin UFL2 sebagai superdisintegran [48].

Koproses pati beras, CCMS dan silikon dioksid (dalam bentuk natrium silikat) dilakukan untuk meningkatkan fungsionalitas secara sinergis dengan menggabungkan dua atau lebih eksipien dengan metode fisika untuk menghilangkan sifat yang tidak diinginkan dari masingmasing eksipien [49]. Koproses pati tersebut menunjukkan kemampuan mengalir dan kompresibilitas yang lebih baik karena dibuat dengan spray dried yang dapat memberikan partikel aglomerat, permukaan yang lebih halus dan distribusi ukuran yang sempit sehingga dapat meningkatkan sifat alir [50]. Koproses pati beras dan silikon dioksida menghasilkan waktu hancur selama 28 detik, sedangkan pati beras alami selama 65,7 detik. Waktu hancur pati koproses lebih cepat dari pati beras alami dapat dilihat dari index swelling pati koproses $(5,37 \%)$ lebih besar dibandingkan pati beras alami (3,49\%). CCMS dapat meningkatkan pembengkakan pati karena gugus hidrofilik karboksimetil [51]. Silikon dioksid yang bersifat higroskopis dan dapat meningkatkan porositas tablet. Semakin tinggi konsentrasi silikon dioksid, maka $\mathrm{pH}$ larutan semakin tinggi dan gelatinisasi pati meningkat [52].

Tabel 3. Evaluasi FDT menggunakan pati hasil modifikasi secara kimia sebagai superdisintegran

\begin{tabular}{|c|c|c|c|c|c|c|c|c|}
\hline $\begin{array}{c}\text { Pati sebagai } \\
\text { Superdisitegran }\end{array}$ & $\begin{array}{c}\text { Kadar } \\
(\%)\end{array}$ & $\begin{array}{c}\text { WH } \\
(\text { detik })\end{array}$ & $\begin{array}{c}\text { WT } \\
(\text { detik })\end{array}$ & $\begin{array}{c}\text { WAR } \\
(\%)\end{array}$ & $\begin{array}{c}\text { Kekerasan } \\
\left(\mathrm{kg} / \mathrm{cm}^{2}\right)\end{array}$ & $\begin{array}{c}\text { Kerapuhan } \\
(\%)\end{array}$ & Disolusi & Sumber \\
\hline $\begin{array}{c}\text { Pati Leucine- } \\
\text { grafted }\end{array}$ & 4 & $<60$ & $<60$ & - & $6.6-7.1$ & $\leq 0.5$ & $\begin{array}{c}90 \% \\
\text { menit } \\
\text { ke-10 }\end{array}$ & {$[7]$} \\
\hline $\begin{array}{c}\text { Pati derivatisasi } \\
\text { dengan } \\
\text { polysuccinimide }\end{array}$ & 2 & $<60$ & $<60$ & - & $\begin{array}{c}137-140 \\
\mathrm{~N}\end{array}$ & 0,3 & $\begin{array}{c}\text { menit } \\
\text { ke-10 }\end{array}$ & {$[10]$} \\
\hline
\end{tabular}

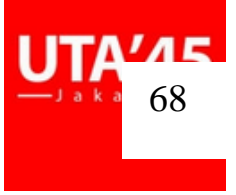




\begin{tabular}{|c|c|c|c|c|c|c|c|c|}
\hline $\begin{array}{l}\text { Pati konjugasi } \\
\text { glycine }\end{array}$ & 5 & 19 & 15 & $52 \%$ & 4,9 & 0,51 & $\begin{array}{l}100 \% \\
\text { pada } \\
\text { menit } \\
\text { ke-60 }\end{array}$ & [39] \\
\hline $\begin{array}{c}\text { Konjugasi pati } \\
\text { jagung-Neusilin } \\
\text { UFL2 (chemical } \\
\text { mixture) }\end{array}$ & 10 & 32 & 22 & 110 & $3,7-4,1$ & $0,51-0,55$ & $\begin{array}{l}70-85 \% \\
\text { menit } \\
\text { ke-60 }\end{array}$ & [6] \\
\hline $\begin{array}{c}\text { Pati modifikasi } \\
\text { asam dari } \\
\text { Borassus } \\
\text { aethiopum } \\
\text { (Aracaceae) }\end{array}$ & 2,43 & 56,92 & - & - & 9,76 & 0.63 & $\begin{array}{l}101,37 \\
\% \text { pada } \\
\text { menit } \\
\text { ke-30 }\end{array}$ & [41] \\
\hline $\begin{array}{c}\text { Kombinasi Pati } \\
\text { xanthate dan } \\
\text { CMC Na }\end{array}$ & $5: 0,5$ & 12 & 76 & 174 & $3,6-4$ & $0,12-0,15$ & $\begin{array}{c}99,84 \\
\text { pada } \\
\text { waktu } \\
\text { menit } \\
\text { ke-5 }\end{array}$ & [40] \\
\hline $\begin{array}{l}\text { Kombinasi pati } \\
\text { kentang dan } \\
\text { glycine }\end{array}$ & $\begin{array}{c}20 \\
(15: 5)\end{array}$ & $\begin{array}{l}44,17- \\
184,83\end{array}$ & $\begin{array}{c}92- \\
>16609\end{array}$ & $\begin{array}{l}38.88- \\
51.37\end{array}$ & $3.29-5.11$ & $0.37-1.09$ & $\begin{array}{l}80 \% \\
\text { pada } \\
\text { menit } \\
\text { ke-30 }\end{array}$ & [14] \\
\hline $\begin{array}{l}\text { Ikatan silang } \\
\text { karboksimetil } \\
\text { pati nangka }\end{array}$ & 2 & 62 & - & - & - & - & - & [35] \\
\hline $\begin{array}{c}\text { Ikatan silang } \\
\text { karboksimetil } \\
\text { pati beras } \\
\text { dengan sodium } \\
\text { silikat }\end{array}$ & 3 & 16,83 & - & - & 4,79 & 0,91 & $\begin{array}{l}80 \% \\
\text { pada } \\
\text { waktu } \\
\text { ke-30 }\end{array}$ & [34] \\
\hline $\begin{array}{l}\text { Ikatan silang } \\
\text { karboksimetil } \\
\text { natrium pati } \\
\text { Kacang }\end{array}$ & 6 & 60 & - & - & 6,2 & 0,29 & $\begin{array}{c}99,48 \\
\text { pada } \\
\text { menit } \\
\text { ke-5 }\end{array}$ & [9] \\
\hline
\end{tabular}

Keterangan : WH (Waktu Hancur); WT (Wetting Time); WAR (Water Absorption Ratio)

Modifikasi pati secara kimia dilakukan dengan menambahkan pereaksi kimia sehingga membentuk suatu substituen baru dapat melalui substitusi, oksidasi dan ikatan silang dan derivatisasi [28]. Waktu hancur pati hasil modifikasi secara kimia dari leucine grafted, derivatisasi dengan polysuccinimide, konjugasi glycine, konjugasi pati jagung-Neusilin UFL2, modifikasi asam dari Borassus aethiopum, kombinasi pati xanthate dan CMC Na, kombinasi pati kentang dan glycine, ikatan silang karboksimetil pati nangka, pati beras dengan sodium silikat 
dan natrium pati kacang memiliki waktu hancur berturut-turut $<60 ;<60 ; 19 ; 32 ; 56,92 ; 12$; 44,17-184,83; 62; 16,83; 60 detik [6][9][10][14][34][35][39]-[41]. Konjugasi pati dengan suatu asam amino endogenik seperti leucine dan glycine, derivatisisasi dengan polysuccinimide, konjugasi pati jagung-Neusilin UFL2 memungkinkan dapat meningkatkan disintegrasi tablet dengan waktu hancur kurang dari 60 detik dapat dilihat pada Tabel 3. Waktu hancur yang lebih cepat ini disebabkan karena leucine mengandung amina $\left(\mathrm{NH}_{2}\right)$ dan memiliki luas permukaan yang besar yang dapat meningkatkan penyerapan air dan pembengkakan pada permukaan pati [53], penambahan bahan bersifat polar dari polysuccinimide memfasilitasi hidrofilitas [54], glycine memiliki sifat pembasahan yang sangat baik [55], Neusilin UFL2 dapat meningkatkan kualitas tablet (sifat alir, disintegrasi, kelarutan) [56], sehingga granula pati menunjukan adanya rongga yang menyebabkan pembengkakan dan penyerapan meningkat karna porositas yang tinggi [48].

Modifikasi pati dengan hidrolisis asam menggunakan $\mathrm{HCl} 6 \%$ b/v pada Borassus aethiopum (Aracaceae) menyebabkan terjadi perubahan fisik dan kimiawi tanpa merusak sifat granular, peningkatan kristalinitas, kelarutan dan sedikit peningkatan sifat alir [8]. Pati xanthate memiliki serbuk berbentuk kristal halus yang mengalir bebas dan menunjukkan pembengkakan yang baik dalam air dengan nilai index swelling sebesar $50 \%$, sehingga jika dikombinasi dengan CMC Na maka swelling yang terjadi semakin besar menyebabkan tablet hancur semakin cepat [40]. Dari semua pati yang dimodifikasi, ikatan silang karboksimetil merupakan salah satu pati yang paling banyak digunakan produk dalam industri makanan dan farmasi karena sifat pembengkakan, pengental dan pembentuk gelnya yang baik [57]. Pati hasil ikatan silang karboksimetilasi dengan $\mathrm{POCl}_{3}$ (fosforil klorida) [9], natrium trimetafosfat [35], epiklorohidrin [34] dapat meningkatkan hidrofilisitas air akibat penambahan bermuatan negatif $\left(\mathrm{CH}_{2} \mathrm{COO}^{-}\right)$[9], meningkatkan serapan dan kelarutan air pati dalam rantai induk pati [58] menyebabkan penetrasi air ke dalam granula pati meningkat dan pembengkakan granula pati. Ikatan silang karboksimetil pada pati nangka menghasilkan pati yang lebih higroskopis, kelarutan meningkat dibandingkan dengan pati nangka alami [35]. Modifikasi karboksimetil pati beras efektif meningkatkan pembengkakan, viskositas, sifat alir, dan kompresibilitas dibandingkan pati beras alami [34].

Tabel 4. Evaluasi FDT menggunakan pati hasil modifikasi secara kombinasi sebagai superdisintegran

\begin{tabular}{|c|c|c|c|c|c|c|c|c|}
\hline $\begin{array}{c}\text { Pati sebagai } \\
\text { Superdisitegran }\end{array}$ & $\begin{array}{c}\text { Kadar } \\
(\%)\end{array}$ & $\begin{array}{c}\text { WH } \\
(\text { detik })\end{array}$ & $\begin{array}{c}\text { WT } \\
(\text { detik })\end{array}$ & $\begin{array}{c}\text { WAR } \\
(\%)\end{array}$ & $\begin{array}{c}\text { Kekerasan } \\
\left(\mathrm{kg} / \mathrm{cm}^{2}\right)\end{array}$ & $\begin{array}{c}\text { Kerapuhan } \\
(\%)\end{array}$ & Disolusi & Sumber \\
\hline $\begin{array}{c}\text { Kombinasi } \\
\text { maltodextrin }\end{array}$ & $10: 30$ & 24,49 & 87,66 & - & 4.35 & 1,49 & - & {$[12]$} \\
$\begin{array}{c}\text { DE 10-15 dan } \\
\text { pati singkong } \\
\text { pregelatinasi }\end{array}$ & 10 & 22 & 13 & 128 & $4,2-4,3$ & $0,41-0,47$ & $\begin{array}{c}70-85 \% \\
\text { menit } \\
\text { ke-60 }\end{array}$ & {$[6]$} \\
\hline $\begin{array}{c}\text { Konjugasi pati } \\
\text { jagung- } \\
\text { Neusilin UFL2 } \\
\text { gelombang } \\
\text { mikro) }\end{array}$ & 10 & & & & & \\
\hline
\end{tabular}

Keterangan : WH (Waktu Hancur); WT (Wetting Time); WAR (Water Absorption Ratio) 
Kombinasi pati singkong pregelatinasi dan maltodekstrin DE 10-15 merupakan kombinasi modifikasi secara fisika dan enzimatis. Pati singkong pregelatinasi ini dibuat dengan memanaskan pati singkong pada suhu $90^{\circ} \mathrm{C}$ dimana pada suhu tersebut pati akan mengembang secara maksimal Pati singkong hasil pregelatinisasi ini memiliki daya alir dan kompresibilitas yang baik, sehingga dapat digunakan untuk induksi langsung [59]. Maltodekstrin DE 10-15 digunakan sebagai pelarut karena kapilaritas dan porositasnya [60]. Maltodekstrin ini merupakan hasil produk dari hidrolisis secara enzimatis dengan alfa-amilase yang mengandung unit $\alpha$-Dglukosa melekat pada $(1 \rightarrow 4)$ glikosida dengan nilai ekuivalen dekstrosa $(\mathrm{DE})<20$. DE merupakan jumlah total gula yang diperoleh dari hasil hidrolisis pati [61].

Kombinasi pati singkong pregelatinasi dan maltodekstrin DE 10-15 menghasilkan waktu hancur 24,49 detik dengan waktu pembasahan 87,66. Waktu pembasahan berkaitan dengan struktur bagian dalam tablet dan hidrofilisitas eksipien [1]. Waktu pembasahan yang cepat dari maltodekstrin DE 10-15 disebabkan oleh hidrofilisitas, porositas, dan kapilaritasnya membuat saliva dengan cepat menembus ke dalam tablet, sehingga semakin tinggi konsentrasi maltodekstrin DE 10-15 yang digunakan, maka waktu pembasahan semakin cepat [62]. Jika konsentrasi maltodekstrin DE 10-15 lebih dari 10\% maka ketika maltodekstrin berada di lingkungan yang berisi air, ia membentuk lapisan gel di sekitar tablet untuk mencegah air menembus [12].

Konjugasi pati jagung-Neusilin UFL2 dilakukan dengan metode gelombang mikro dimana dilakukan pencampuran secara fisika dengan tumbling mixer dan radiasi dengan gelombang mikro 590 watt tidak lebih dari 5 menit hasil modifikasi ini memiliki nilai swelling index sebesar 95\% yang jauh lebih baik dibandingkan pati jagung alami sebesar 18\%. Meningkatnya nilai swelling index menyebabkan waktu hancur FDT dengan pati hasil modifikasi lebih cepat (22 detik) jika dibandingkan dengan pati jagung alami (71 detik) dapat dilihat pada Tabel 4. Hal ini disebabkan karena pati jagung-Neusilin UFL2 memiliki porositas yang tinggi sehingga waktu hancur tablet lebih cepat karena tablet lebih cepat terbasahi [63].

Berdasarkan uraian diatas, FDT dengan pati alami sebagai superdisntegran memiliki waktu hancur berkisar 2-3 menit, sedangkan pati hasil modifikasi memiliki waktu hancur kurang dari 1 menit. Hal ini menunjukkan modifikasi yang dilakukan baik secara fisika, kimia, enzimatis maupun kombinasi memberikan waktu hancur yang lebih cepat dibandingkan pati alami. Efisiensi suatu modifikasi dapat dipengaruhi dari sumber pati, rasio amilosa dengan amilopektin, morfologi granula pati, jenis serta konsentrasi reagen modifikasi yang digunakan [29]. Berdasarkan modifikasi pati yang dilakukan mengkombinasikan pati xanthate dan $\mathrm{CMC} \mathrm{Na}$ memberikan waktu hancur 12 detik, modifikasi pati beras ikatan silang karboksimetil dengan sodium silikat memberikan waktu hancur 16,83 detik dan modifikasi pati dengan konjugasi glycine memberikan waktu hancur 19 detik merupakan modifikasi pati secara kimia dapat memberikan waktu hancur tercepat dibandingkan dengan modifikasi pati lainnya. 


\section{DAFTAR RUJUKAN}

[1] D. Bhowmik., B. Chiranjib., R. M. Chandira. Fast Dissolving Tablet an Overview. J Chem Pharm Res. 2009, 1(1), 163-177.

[2] R. Pahwa., M. Piplani., P. C. Sharma., D. Kaushik and SN. Orally Disintegrating Tablets Friendly to Pediatrics and Geriatrics. Arch Appl Sci Res. 2010, 02(02), 35-48.

[3] W. Zhang., Y. Wang., X. Gao., S. Peng., Y. Zheng. Optimization of Oral Fast Disintegrating Tablets Based on Response Surface-Central Composite Design. 2013, 5(2), 138-144.

[4] V. Suryadevara., S. R. Lankapalli., L. H. Danda., V. Pendyala., V. Katta. Studies on Jackfruit Seed Starch as a Novel Natural Superdisintegrant for The Design and Evaluation of Irbesartan Fast Dissolving Tablets. Integr Med Res [Internet]. 2017, 6(3), 280-291.

[5] M. C Eryani., S. Wikarsa., Y. C. Soemirtapura. Formulasi dan Evaluasi Fast Disintegrating Tablet (FDT) Loratadin. Acta Pharm Indonesia. 2018, 39(1 \& 2), 26-32.

[6] P. Juneja., B. Kaur., O. A. Odeku., I. Singh. Development of Corn Starch-Neusilin UFL2 Conjugate as Tablet Superdisintegrant: Formulation and Evaluation of Fast Disintegrating Tablets. J Drug Deliv. 2014, 1-13.

[7] M. Sadeghi., S. Hemmati., R. Salehi., M. Solhi., M. Ghorbani., H. Hamishehkar. Leucine-Grafted Starch as a New Superdisintegrant for The Formulation of Domperidone Tablets. J Drug Deliv Sci Technol. 2019,136-144.

[8] S. O. Eraga., V. N. Nwajuobi., M.A. Iwuagwu. Superdisintegrant Activity of Acid-Modified Millet Starch in Diclofenac Tablet Formulations. J Sci Pract Pharm. 2017, 4(1), 161-168.

[9] A. V. Singh., L. K. Nath., M. Guha., R. Kumar. Microwave Assisted Synthesis and Evaluation of Modified Pea Starch as Tablet Superdisintegrant. Current Drug Delivery. 2011, 8, 203-207.

[10] M. Sadeghi., S. Hemmati., H. Hamishehkar. Synthesis of a Novel Superdisintegrant by Starch Derivatization With Polysuccinimide and Its Application for The Development of Ondansetron Fast Dissolving Tablet. Drug Dev Ind Pharm. 2016, 42(5), 769-775.

[11] D. Sharma. Formulation Development and Evaluation of Fast Disintegrating Tablets of Salbutamol Sulphate for Respiratory Disorders. ISRN Pharm. 2013, 1-8.

[12] A. Zaki., E. Anwa., S. Surini. Formulation of a Fast-Disintegrating Tablet Using Maltodextrin DE 10-15 and Pregelatinizated Cassava Starch as Expedients. Int J Appl Pharm. 2017, 9, 71-73.

[13] A. N. Bestari., T. N. S. Sulaiman., A. Rohman. Formulasi Orally Disintegration Tablet (ODT) Meloksikam Dengan Variasi Komposisi Ac-Di-Sol dan Kollidon Cl® Sebagai Bahan Penghancur. Maj Farm. 2016, 12(2), 453-465.

[14] E. Monica., R. Rollando., R. Sitepu., D. R. K. Nisah., L. N. Irawati., S. D. L. Listio. Formulation of Fast Disintegrating Tablet Paracetamol Employing Selected Super-Disintegrant. Int J Res Pharm Sci. 2020, 11(3), 4323-4333.

[15] Y. Fu., S. Yang., S. H. Jeong., S. Kimura., K. Park. Orally Fast Disintegrating Tablets: Developments, Technologies, Taste-Masking and Clinical Studies. Crit Rev Ther Drug Carrier Syst. 2004, 21(6), 433-475.

[16] T. Kaur., B. Gill., S. Kumar., G. D. Gupta. Mouth Dissolving Tablets: A Novel Approach to Drug Delivery. Int J Pharm Res. 2011, 3(1), 1-7.

[17] H. Shihora., S. Panda. Superdisintegrants Utility In Dosage Forms : A Quick Review. J Pharm Sci Biosci Res. 2011, 1(3), 148-153.

[18] R. Bala., S. Khanna., P. Pawar. Polymers In Fast Disintegrating Tablets - A Review. Asian J Pharm Clin Res. 2012, 5(2), 8-14.

[19] K. Huanbutta., W. Sittikijyothin. Development and Characterization of Seed Gums From Tamarindus Indica and Cassia Fistula as Disintegrating Agent for Fast Disintegrating Thai Cordial Tablet. Asian J Pharm Sci. 2017, 12(4), 370-377.

[20] N. D. Yadav., P. L. Pingale., S. R. Tatane. Comparative Study on Effect of Natural and Artificial

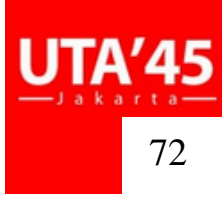


Superdisintegrants In The Formulation of Fast Dissolving Aspirin Tablet. 2010, 3(7).

[21] R. Malviya., P. Srivastava., M. Bansal., P. K. Sharma. Mango Peel Pectin as a Superdisintegrating Agent. J Sci Ind Res. 2010, 69(9), 688-690.

[22] E. Sipos., A. R. Oltean., Z. I. Szabó., E. M. Rédai., G. D. Nagy. Application of SeDeM Expert Systems In Preformulation Studies of Pediatric Ibuprofen ODT Tablets. Acta Pharm. 2017, 67(2), 237-246.

[23] A. Kumar., V. A. Saharan. A Comperative Study of Different Proportions of Superdisintegrants: Formulation and Evaluation of Orally Disintegrating Tablets of Salbutamol Sulphate. Turkish J Pharm Sci. 2017, 14(1), 40-48.

[24] S. L. M. El Halal., D. H. Kringel., E. Zavareze., A. R. G. Dias. Methods for extracting Cereal Starches from Different Sources: A Review. Starch/Staerke. 2019, 71(11-12), 1-14.

[25] Irhami., C. Anwar., M. Kemalawaty. Physicochemical Properties of Sweet Potato Starches by Studying Their Varieties and Drying Temperatures. J Teknol Pertan. 2019, 20(1), 33-44.

[26] S. Winarti S., Y. Purnomo. Olahan Biji Buah. Surabaya: Trubus Agrisarana; 2006.

[27] K. Syahraeni. Karakterisasi Tepung Empat Varietas Pisang di Lembah Palu. J Agrisains. 2005, 6, $1-6$.

[28] M. A. V. T. Garcia., C. F. Garcia., A. A. G. Faraco. Pharmaceutical and Biomedical Applications of Native and Modified Starch: A Review. Starch/Staerke. 2020, 72(7-8), 1-15.

[29] A. Korma S. Chemically Modified Starch and Utilization In Food Stuffs. Int J Nutr Food Sci. 2016, 5(4), 264.

[30] M. Venkatarao., S. Vidyadhara., D. Sandeep. Formulation and Evaluation of Atorvastatin Fast Dissolving Tablets Using Entada Scandens Seed Starch as Superdisintegrant. Asian J Pharm. 2018, 12(3), 170-181.

[31] B. M. J. Martens., W. J. J. Gerrits., Bruininx., H. A. Schols. Amylopectin Structure and Crystallinity Explains Variation in Digestion Kinetics of Starches Across Botanic Sources in an In Vitro Pig Model. J Anim Sci Biotechnol. 2018, 9(1).

[32] L. F. Wang., S. Y. Pan., H. Hu., W. H. Miao., X. Y. Xu. Synthesis and Properties of Carboxymethyl Kudzu Root Starch. Carbohydr Polym. 2010, 80(1), 174-179.

[33] K. Trisopon., N. Kittipongpatana., O. S. Kittipongpatana. A Spray-Dried, Co-Processed Rice Starch as a Multifunctional Excipient for Direct Compression. Pharmaceutics. 2020, 12(6), 1-18.

[34] K. Trisopon., O. S. Kittipongpatana. Development of a Direct Compression Excipient from Epichlorohydrin-Crosslinked Carboxymethyl Rice Starch with Sodium Silicate Using a Coprocessing Technique. Starch/Staerke. 2019, 71(5-6), 1-8.

[35] N. Kittipongpatana., S. Janta., O. Kittipongpatana. Preparation of Cross-Linked Carboxymethyl Jackfruit Starch and Evaluation as a Tablet Disintegrant. J Pharm Sci. 2011, 24(4), 415-420.

[36] B. Zhang., S. Dhital., E. Haque., M. J. Gidley. Preparation and Characterization of Gelatinized Granular Starches from Aqueous Ethanol Treatments. Carbohydr Polym. 2012, 90(4),1587-1594.

[37] E. Aulton Michael., K. M. Taylor. Aulton's Pharmaceutical The Design and Manufacture of Medicines 4th Edition. UK: Elsivier; 2013.

[38] Dachriyanus. Analisis Struktur Senyawa Organik Secara Spektroskopi. Lembaga Pengembangan Teknologi Informasi dan Komunikasi (LPTIK); 2004.

[39] I. Singh., B. Sharma., G. Arora. Application of SeDeM Expert System in Formulation and Development of Fast Disintegrating Tablets Using Starch-Glycine Conjugates as Superdisintegrant. J Res Pharm. 2019, 23(5), 839-850.

[40] R. Santosh Kumar., T. Naga Satya Yagnesh. Synthesis, Characterization and Evaluation of Starch Xanthate as a Superdisintegrant in The Formulation of Fast Dissolving Tablets. Int J Appl Pharm. 2018, 10(6), 249-258.

[41] C. P. Azubuike., U. N. Ubani-Ukoma., A. R. Afolabi., I. M, Cardoso-Daodu. Evaluation of SuperDisintegrant Potential of Acid-Modified Starch Derived from Borassus Aethiopum (Aracaceae)

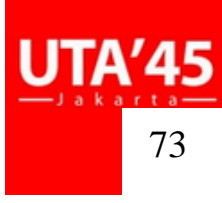


Shoot In Paracetamol Tablet Formulations. Trop J Pharm Res. 2020, 19(3), 459-465.

[42] P. M. DesaI., C. V. Liew., P. W. S. Heng. Review of Disintegrants and the Disintegration Phenomena. J Pharm Sci. 2016, 105(9), 2545-2555.

[43] P. M. Desai., P. X. H. Er., C. V. Liew., P. W. S. Heng. Functionality of Disintegrants and Their Mixtures in Enabling Fast Disintegration of Tablets by a Quality by Design Approach. AAPS PharmSciTech. 2014, 15(5), 1093-1104.

[44] W. Brniak., R. Jachowicz., P. Pelka. The Practical Approach to The Evaluation of Methods Used to Determine The Disintegration Time of Orally Disintegrating Tablets (ODTs). Saudi Pharm J. 2015, 23(4), 437-443.

[45] D. Sharma., D. Kumar., M. Singh., G. Singh., M. S. Rathore. Fast Disintegrating Tablets: A New Era in Novel Drug Delivery System and New Market Opportunities. J Drug Deliv Ther. 2012, 2(3), 74-86.

[46] K. Chauhan., R. Solanki., S. Sharma. A Review on Fast Dissolving Tablet. Int J Appl Pharm. 2018, 10(6), 1-7.

[47] M. V. Lawal., M. A. Odeniyi., O. A. Itiola. Effect of Thermal and Chemical Modifications on The Mechanical and Release Properties of Paracetamol Tablet Formulations Containing Corn, Cassava and Sweet Potato Starches as Filler-Binders. Asian Pac J Trop Biomed. 2015, 5(7), 585590.

[48] O. A. Odeku., B. L. Akinwande. Effect of The Mode of Incorporation on The Disintegrant Properties of Acid Modified Water and White Yam Starches. Saudi Pharm J. 2012, 20(2), 171175.

[49] J. Rojas., I. Buckner., V. Kumar. Co-Proccessed Excipients With Enhanced Direct Compression Functionality for Improved Tableting Performance. Drug Dev Ind Pharm. 2012, 38(10), 11591170.

[50] A. Mitrevej., N. Sinchaipanid., D. Faroongsarng. Spray-Dried Rice Starch: Comparative Evaluation of Direct Compression Fillers. Drug Dev Ind Pharm. 1996, 22(7), 587-594.

[51] O. S. Kittipongpatana., N. Kittipongpatana. Physicochemical, In Vitro Digestibility and Functional Properties of Carboxymethyl Rice Starch Cross-Linked With Epichlorohydrin. Food Chem. 2013, 141(2), 1438-1444.

[52] F. Alam., A. Hasnain. Studies on Swelling and Solubility of Modified Starch from Taro (Colocasia Esculenta): Effect Of pH and Temperature. Agric Conspec Sci. 2009, 74(1), 45-50.

[53] S. Shojaee., A. Nokhodchi., M. Maniruzzaman. Evaluation of The Drug Solubility and Rush Ageing on Drug Release Performance of Various Model Drugs from The Modified Release Polyethylene Oxide Matrix Tablets. Drug Deliv Transl Res. 2017, 7(1), 111-124.

[54] N. Bashardoust., J. L. Jenita., P. Zakeri-Milani. Preparation and In Vitro Investigation of Chitosan Compressed Tablets for Colon Targeting. Adv Pharm Bull. 2011, 1(2), 87-92.

[55] J. Fukami., E. Yonemochi., Y. Yoshihashi., K. Terada. Evaluation of Rapidly Disintegrating Tablets Containing Glycine and Carboxymethyl Cellulose. Int J Pharm. 2006, 310(1-2), 101-109.

[56] J. M. Sonnergaard. Impact of Particle Density and Initial Volume on Mathematical Compression Models. Eur J Pharm Sci. 2000, 11(4), 307-315.

[57] O. S. Kittipongpatana., J. Sirithunyalug., R. Laenger. Preparation and Physicochemical Properties of Sodium Carboxymethyl Mungbean Starches. 2006, 63, 105-112.

[58] O. S. Kittipongpatana., W. Chaitep., N. Kittipongpatana. Physicochemical and Pharmaceutical Properties of Cross-Linked Carboxymethyl Rice Starch Prepared by a Simultaneous Dual Reaction. 2010, 214-220.

[59] A. Wade., P. J. Weller. Handbook of Pharmaceutical Excipient. 6 th. London: The Pharmaceutical Press; 2009.

[60] E. Anwar., J. Djajadisastra., A. Yanuar., A. Bahtiar. Pemanfaatan Maltodekstrin Pati Terigu sebagai Eksipien dalam Formula Sediaan Tablet dan Niosom. Maj Ilmu Kefarmasian. 2004, 1(1),

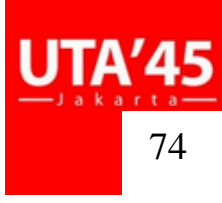


34-46.

[61] M. W. Kearsley., S. Z. Dziedzic. Handbook of Starch Hydrolisis Products and Their Derivatives. London: Blackie Academy Professional; 1995.

[62] Y. Gonnissen., J. P. Remon., C. Vervaet. Effect of Maltodextrin and Superdisintegrant in Directly Compressible Powder Mixtures Prepared Via Co-Spray Drying. Eur J Pharm Biopharm. 2008, 68(2), 277-282.

[63] M. A. Odeniyi., J. O. Ayorinde. Effects of Modification and Incorporation Techniques on Disintegrant Properties of Wheat (Triticum Aestivum) Starch in Metronidazole Tablet Formulations. Polim Med. 2014, 44(3), 147-155. 